\title{
Pengaruh Metode Mind Mapping Menggunakan Aplikasi mi-Mind Serta Edmodo Terhadap Prestasi Belajar Komputer dan Jaringan Dasar
}

\author{
Komang Lilis Hermawati ${ }^{*}$, Nyoman Sugihartini ${ }^{2}$, Gede Saindra Santyadiputra ${ }^{3}$ \\ ${ }^{123}$ Prodi Pendidikan Teknik Informatika Universitas Pendidikan Ganesha
}

\author{
A R T I C L E I N F O \\ Article history: \\ Received 19 January 2019 \\ Received in revised form \\ 10 February 2019 \\ Accepted 12 March 2019 \\ Available online 25 April \\ 2019 \\ Kata Kunci: \\ Metode mind mapping, \\ Edmodo, Media \\ pembelajaran, Prestasi \\ belajar \\ Keywords: \\ Mind mapping methods, \\ Edmodo, learning media \\ learning achievements
}

\begin{abstract}
A B S T R A K
Penelitian ini bertujuan untuk mengetahui (1) perbedaan peningkatan prestasi belajar antara siswa dengan metode mind mapping menggunakan aplikasi mi-Mind serta Edmodo dan siswa dengan metode ceramah menggunakan media powerpoint (2) respon siswa setelah menggunakan metode mind mapping dengan aplikasi miMind serta Edmodo. Jenis penelitian ini adalah eksperimen semu dengan desain Posttest-Only Control Design. Metode pengumpulan data yang digunakan yaitu metode tes untuk mengukur prestasi belajar dan metode angket untuk mengukur respon siswa. Data prestasi belajar kemudian dianalisis menggunakan t-tes dengan taraf signifikansi 0,05 dan uji prasyarat, yaitu uji normalitas dan uji homogenitas. Hasil penelitian menunjukkan (1) terdapat perbedaan peningkatan prestasi belajar antara siswa dengan metode mind mapping menggunakan aplikasi mi-Mind serta Edmodo dan siswa dengan metode ceramah menggunakan media powerpoint. Hasil analisis menunjukkan |thitung $|>|$ ttabel| $(20,084>2,2928)$ maka HO ditolak dan $\mathrm{H} 1$ diterima. (2) respon siswa menunjukan nilai positif.
\end{abstract}

\section{A B S T R A C T}

This study aims to determine (1) the difference in the improvement of learning achievement between students with the mind mapping method using the mi-Mind and Edmodo applications and students with the lecture method using PowerPoint media (2) student responses after using the mind mapping method with the mi-Mind and Edmodo applications. This type of research is a quasiexperimental design with Posttest-Only Control Design. Data was collected was to measure learning achievement and questionnaire methods to measure student responses. Learning achievement data were then analyzed by using t-tests with a significance level of 0.05 and prerequisite tests, normality and homogeneity tests. The results showed (1) there was a difference in the increase in learning achievement between students with the mind mapping method using the mi-Mind application and Edmodo and students with the lecture method using PowerPoint media. The analysis shows that | tcount $|>| \mathrm{t}$ table $\mid(20,084>2.2928)$ then $\mathrm{H} 0$ was rejected and $\mathrm{H} 1$ was accepted. (2) student responses showed positive values.

\footnotetext{
* Corresponding author.

E-mail addresses: komanglilis@gmail.com (Komang Lilis Hermawati)
} 


\section{Pendahuluan}

Pendidikan merupakan suatu proses akademik yang tujuannya untuk meningkatkan nilai sosial, budaya, moral, dan agama, serta mempersiapkan pembelajar menghadapi tantangan dan pengalaman dalam kehidupan nyata (Munir, 2009). Dalam meningkatkan mutu sumber daya manusia (SDM) dapat dipengaruhi oleh beberapa faktor, salah satunya adalah pembelajaran. Pembelajaran merupakan proses yang bukan hanya proses pengungkapan ilmu pengetahuan saja, melainkan juga suatu proses pencarian ilmu pengetahuan secara aktif atau proses perumusan ilmu pengetahuan (Munir, 2009). Untuk itu diperlukan proses pembelajaran yang efektif dan efisien agar peserta didik dapat menyerap informasi dan pengetahuan serta teknologi yang dipelajari.

Menurut Undang-undang Nomor 20 Tahun 2003 tentang Sistem Pendidikan Nasional pasal 13 ayat 1, jalur pendidikan terdiri atas jalur pendidikan formal, nonformal dan informal yang saling melengkapi dan memperkaya. SMK merupakan jenjang sekolah yang peserta didiknya diarahkan untuk mempunyai keahlian tertentu, sehingga mata pelajaran yang diberikan berbeda dari mata pelajaran di Sekolah Menengah Atas (SMA). Siswa SMK dituntut bisa mengikuti mata pelajaran normatif, adaptif dan mata pelajaran produktif yang ada di sekolah. Untuk menghasilkan lulusan yang kompeten di bidangnya dan sesuai kemampuan yang dimiliki. Prestasi Belajar digunakan untuk mengetahui sebatas mana siswa dapat memahami serta mengerti materi tersebut.

Dewasa ini Ilmu Pengetahuan dan Teknologi (IPTEK) berkembang pesat. Perkembangan ini memiliki dampak semakin terbuka dan tersebarnya informasi dan pengetahuan dari dan ke seluruh dunia menembus batas jarak, tempat, ruang dan waktu. Pemanfaatan teknologi untuk pendidikan semakin berkembang pesat, banyak aplikasi-aplikasi yang dibuat untuk mempermudah proses pembelajaran yang dikemas menarik dan inovatif (Prawiradilaga, 2013). Perkembangan IPTEK sangat mendukung keberhasilan pembelajaran karena dapat memberikan pemahaman yang lebih, penyajian materi pembelajaran lebih menarik, menciptakan lingkungan belajar yang kondusif serta dapat menghemat waktu tenaga dan biaya (Munir, 2009).

Namun kenyataanya hal tersebut tidak sepenuhnya terjadi. Upaya-upaya yang telah ditempuh pemerintah tersebut ternyata belum diterapkan dengan optimal. Dari hasil wawancara dan observasi awal yang dilakukan di SMK Negeri 3 Singaraja menunjukkan prestasi belajar ulangan akhir semester ganjil peserta didik mata pelajaran Komputer dan Jaringan Dasar kelas X dari 106 siswa 74,52\% belum bisa memenuhi Kriteria Ketuntasan Minimum (KKM). Selain itu dalam proses pembelajaran peserta didik hanya mendengarkan guru menjelaskan dan sedikit siswa yang mencatat. Peserta didik lebih suka memecahkan masalah secara berkelompok, banyak peserta didik yang masih takut dan kurang percaya diri untuk mengemukakan pendapat didepan teman-temannya. Pemahaman konsep yang kurang mengakibatkan daya ingat juga ikut berkurang dan peserta didik kurang mampu dalam mengaitkan informasi yang diketahui dengan konsep yang dimiliki yang mengakibatkan kebingungan dalam memecahkan masalah. Sekolah mempunyai kewajiban menyelesaikan semua materi yang ada agar tercapai target kurikulum sesuai dengan waktu yang ditentukan. Sehingga sebagian besar waktu belajar akan digunakan untuk mendengarkan materi yang disampaikan oleh guru untuk mencapai ketuntasan materi.

Berdasarkan kondisi tersebut diketahui bahwa metode dan media sangat penting untuk menunjang proses pembelajaran. Metode mind mapping (peta pikiran) dikenal sebagai pembelajaran yang inovatif. Metode mind mapping dapat membantu siswa membuat catatan yang tidak monoton. Mind mapping tidak hanya digunakan untuk membuat sebuah catatan tetapi juga dapat dimanfaatkan untuk merekam pola pikir kedalam bentuk tertulis.

Selain metode, media pembelajaran juga sangat berperan penting untuk kelancaran proses pembelajaran. Dengan kemajuan IPTEK saat ini dalam dunia pendidikan memunculkan istilah e-learning. Sebagaimana yang dikemukakan oleh Smaldino, dkk. e-learning adalah proses belajar yang memanfaatkan sumber belajar bersifat elektronik, dan berbantuan komputer, namun tidak selalu harus terhubung dengan internet (Prawiradilaga, 2013). Dengan e-learning peserta didik dapat dengan mudah mengakses proses pembelajaran dimanapun dia berada (Munir, 2009).

Sebuah penelitian sebelumnya yang dilakukan oleh (Silaban, 2012) dengan judul "Pengaruh Media Mind Mapping Terhadap Kreativitas Dan Prestasi Belajar Kimia Siswa SMA Pada Pembelajaran Menggunakan Advance Organizer", menyatakan pembelajaran dengan mind maping berpengaruh secara signifikan terhadap Prestasi Belajar siswa. Prestasi Belajar siswa diyakini 96,8\% pada pembelajaran hidrokarbon. Sebuah penelitian lain oleh (Wirda, 2014) yang dilakukan di SMK dengan judul "Pengaruh Penggunaan Media Pembelajaran Elektronik Berbasis Edmodo Terhadap Prestasi Belajar Siswa Pada Mata Diklat Melakukan Instalasi Sound System Kelas XI Teknik Audio Video Di SMK N 1 Kinali", menyatakan 
peningkatan Prestasi Belajar dengan menggunakan media pembelajaran elektronik berbasis edmodo berpengaruh sebesar 6,97\% terhadap Prestasi Belajar siswa.

Berdasarkan hal tersebut penulis tertarik untuk menerapkan e-Learning Edmodo dengan metode pembelajaran Mind Mapping menggunakan aplikasi mi-Mind dalam pembelajaran Komputer dan Jaringan Dasar.

\section{Metode}

Penelitian ini bertujuan untuk mengetahui pengaruh metode mind mapping menggunakan aplikasi mi-Mind serta Edmodo terhadap Prestasi Belajar siswa. Jenis penelitian eksperimen yang digunakan dalam penelitian ini adalah penelitian eksperimen semu (quasi experiment).

Rancangan eksperimen yang digunakan adalah Posttest-Only Control Design dengan gambar desain seperti Gambar 1.

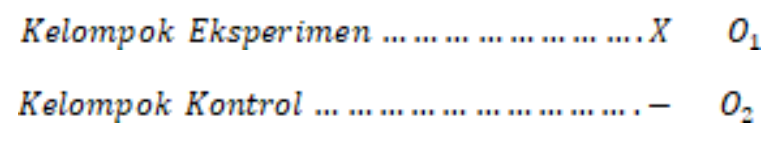

Gambar 1. Post-test Only Control Design

Dari Gambar 1, dapat dijelaskan terdapat dua kelompok yaitu kelompok eksperimen dan kelompok kontrol, $\mathrm{X}$ adalah perlakuan metode mind mapping menggunakan aplikasi mi-Mind serta Edmodo, $\mathrm{O}_{1}$ adalah post-test pada kelompok eksperimen, dan $\mathrm{O}_{2}$ adalah post-test pada kelompok kontrol.

Dalam penelitian ini terdapat dua variabel yaitu variabel independen dan variabel dependen. Variabel independen yang dimaksud dalam penelitian ini adalah metode mind mapping menggunakan aplikasi mi-Mind serta Edmodo. Variabel dependen yang dimaksud dalam penelitian ini adalah Prestasi Belajar mata pelajaran Komputer Dan Jaringan Dasar siswa kelas X TKJ SMK Negeri 3 Singaraja. Diagram hubungan varibel penelitian dapat dilihat pada Gambar 2.

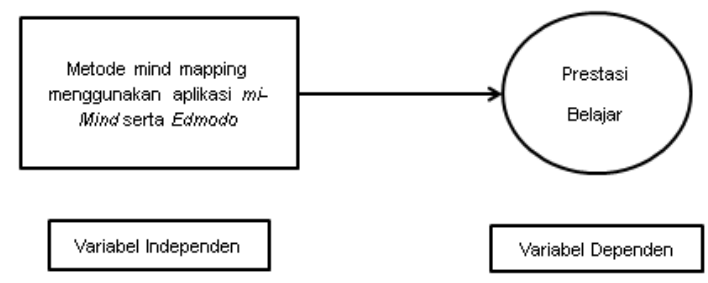

Gambar 2 Diagram Hubungan Variabel Penelitian

Populasi penelitian ini adalah seluruh siswa kelas X TKJ SMK N 3 Singaraja pada semester genap tahun ajaran 2018/2019 dengan sebaran siswa pada Tabel 1.

Tabel 1. Sebaran Anggota Populasi

\begin{tabular}{lll}
\hline No & Kelas & Banyak Siswa \\
\hline 1 & X TKJ 1 & 36 \\
2 & X TKJ 2 & 35 \\
3 & X TKJ 3 & 35 \\
Jumlah & & 106 \\
\hline
\end{tabular}

Tabel 1 menunjukkan bahwa dalam tiga kelas siswa tersebar secara acak. Pengambilan sampel penelitian dilakukan dengan teknik Probability Sampling yaitu teknik Simple Random Sampling. Untuk kelompok eksperimen adalah kelas X TKJ 1 sedangkan kelompok kontrol X TKJ 2.

Instrumen penelitian yang digunakan adalah tes dan angket. Tes prestasi belajar digunakan untuk memperoleh prestasi belajar, sedangkan angket digunakan untuk memperoleh respon siswa. Data prestasi belajar diambil dalam bentuk ujian tertulis di akhir pembelajaran, lembar observasi pada aspek afektif di ambil pada saat proses diskusi berlangsung yang berkaitan aspek sikap siswa,sedangkan data untuk ranah psikomotor diambil selama proses proyek berlangsung melalui rubrik penskoran yang berkaitan dengan kinerja siswa. 
Teknik analisis data dilakukan dengan uji normalitas sebaran data, uji homogenitas varian, dan uji hipotesis. Pengujian hipotesis pada pelitian ini menggunakan t-tes yaitu (Kuswanto, 2012) sparated varians ataupun polled varians.

Rumus Sparated Varians :

$$
t=\frac{\overline{X_{1}}-\overline{X_{2}}}{\sqrt{\frac{s_{1}^{2}}{n_{1}}+\frac{s_{2}^{2}}{n_{2}}}}
$$

Rumus Polled Varians :

$$
t=\frac{\overline{X_{1}}-\overline{X_{2}}}{\sqrt{\frac{\left(n_{1}-1\right) s_{1}^{2}+\left(n_{2}-1\right) s_{2}^{2}}{n_{1}+n_{2}-2}+\left(\frac{1}{n_{1}}+\frac{1}{n_{2}}\right)}}
$$

Keterangan :

$$
\begin{aligned}
& \overline{X_{1}} \text { eksperimen } \\
& \overline{X_{2}} \quad \text { : Nilai rata - rata skor kelompok kontrol } \\
& n_{1} \text { eksperimen } \\
& \text { : Banyaknya siswa kelompok } \\
& n_{2} \quad \text { : Banyaknya siswa kelompok kontrol } \\
& s_{1}^{2} \quad \text { : Varians kelompok eksperimen } \\
& s_{2}^{2} \quad \text { : Varians kelompok kontrol }
\end{aligned}
$$

Rumus Sparated Varians ataupun Polled Varians digunakan dengan ketentuan sebagai berikut:

1) Jumlah anggota sampel $n_{1}=n_{2}$, dan data berdistribusi normal dan varians homogen, dapat digunakan rumus t-test untuk separated varians maupun polled varians dengan derajat kebebasan yang digunakan adalah $\mathrm{dk}=\mathrm{n}_{1}+\mathrm{n}_{2}-2$.

2) Jumlah anggota sampel $\mathrm{n}_{1} \neq \mathrm{n}_{2}$, varians homogen dapat digunakan t-test dengan polled varians dengan derajat kebebasan yang digunakan adalah $\mathrm{dk}=\mathrm{n}_{1}+\mathrm{n}_{2}-2$.

3) Jumlah anggota sampel $\mathrm{n}_{1}=\mathrm{n}_{2}$, dan varians tidak homogen, dapat digunakan rumus t-test untuk separated varians maupun polled varians dengan derajat kebebasan yang digunakan adalah $\mathrm{dk}=\mathrm{n}_{1}-1$ atau $\mathrm{dk}=\mathrm{n}_{2}-1$.

4) Jumlah anggota sampel $n_{1} \neq n_{2}$ dan varians tidak homogen, dapat digunakan t-test dengan polled varians dengan derajat kebebasan yang digunakan adalah selisih harga $t_{\text {tabel }}$ dengan $\mathrm{dk}=\mathrm{n}_{1}-1 \mathrm{dan} d \mathrm{k}$ $=\mathrm{n}_{2}-1$ dibagi dua, kemudian ditambah dengan harga t yang terkecil.

5) Kriteria pengujian adalah terima $H_{0}$ dan tolak $H_{1}$ jika $t_{\text {hitung }} \leq t_{\text {tabel, }}$, tolak $H_{0}$ dan terima $H_{1}$ jika $t_{\text {hitung }}>$ $t_{\text {tabel.. }}$

Uji normalitas digunakan untuk memastikan bahwa data yang diperoleh adalah berdistribusi normal atau tidak. Uji normalitas dilakukan dengan statistic Kolmogorov-Smirnov dengan rumus sebagai berikut.

$$
\mathrm{D}=\mathrm{F}_{\mathrm{s}}(\mathrm{x})-\mathrm{F}_{\mathrm{t}}(\mathrm{x}) \mid \max
$$

Keterangan:

$\mathrm{F}_{\mathrm{s}}(\mathrm{x})=$ distribusi frekuensi kumulatif sampel

$\mathrm{F}_{\mathrm{t}}(\mathrm{x})=$ distribusi frekuensi kumulatif teoritis

Kriteria pengujian yang digunakan adalah data memiliki sebaran normal jika angka signifikansi yang dihasilkan lebih dari 0,05 dan dalam hal lain data tidak berdistribusi normal.

Uji homogenitas varian digunakan uji F untuk menguji homogenitas antar dua kelompok. Uji homogenitas dengan uji $\mathrm{F}$ dilakukan dengan rumus berikut.

$$
\mathrm{F}=\frac{S_{\text {terubsar }}}{\text { Starkecil }}
$$

Kriteria pengujian adalah terima $\mathrm{H}_{0}$ pada taraf signifikansi $5 \%(\alpha=0,05)$ jika hasil pengujiannya menunjukkan bahwa $\mathrm{F}_{\text {hitung }}<\mathrm{F}_{\text {tabel, }}$, maka semua varians homogen. 


\section{Hasil dan pembahasan}

1. Deskripsi Data

Data Prestasi Belajar diambil dari nilai post-test dari kelompok eksperimen dan kelompok kontrol. Data penelitian ini diperoleh melalui penilaian yang dilakukan pada akhir pembelajaran.

Dari hasil perhitungan secara statistik, maka didapatkan nilai rata-rata $(\mathrm{x})$, simpangan baku $(\mathrm{S})$, dan varians (S2) pada kelas eksperimen dan kelas kontrol seperti pada Tabel 2.

Tabel 2. Analisis Deskriptif Data Kelas Eskperimen dan Kelompok Kontrol

\begin{tabular}{lllll}
\hline $\boldsymbol{K E} \boldsymbol{L} \boldsymbol{A} \boldsymbol{S}$ & $\boldsymbol{N}$ & $\overline{\boldsymbol{X}}$ & $\boldsymbol{S}^{2}$ & $\boldsymbol{S}$ \\
\hline EKSPERIMEN & 34 & 83,70 & 60,51 & 7,77 \\
KONTROL & 35 & 45,27 & 65,82 & 8,11 \\
\hline
\end{tabular}

Dari Tabel 2 terlihat bahwa nilai rata-rata kelas eksperimen lebih tinggi daripada kelas kontrol. Untuk mengetahui apakah perbedaan nilai antara kedua sampel ini perlu dilakukan analisis statistik berupa uji kesamaan dua rata-rata.

2. Analisis Data

Sebelum menarik kesimpulan dari hasil penelitian ini, dilakukanlah analisis data melalui uji hipotesis secara statistik untuk seluruh ranah. Perhitungan uji prasyarat dilakukan dalam dua buah uji yakni uji normalitas dan uji homogenitas.

Tabel 3. Hasil Uji Normalitas Sebaran Data

\begin{tabular}{lllll}
\hline \multirow{2}{*}{ NILAI KOGNITIF } & \multirow{2}{*}{ KELOMPOK } & \multicolumn{3}{l}{ Kolmogorov-Smirnov $^{a}$} \\
\cline { 2 - 5 } & & Statistik & $d f$ & Sig. \\
\cline { 2 - 5 } & Eksperimen & 0,140 & 34 & 0,087 \\
& Kontrol & 0,118 & 35 & $0,200^{*}$ \\
\hline
\end{tabular}

Berdasarkan Tabel 3 nilai statistik Kolmogorov-Smirnov pada data statistik nilai Prestasi Belajar Komputer dan Jaringan Dasar kelompok eksperimen dan kontrol adalah 0,140 dan 0,118 dengan nilai signifikan sebesar 0,087 dan 0,200. Berdasarkan hasil tersebut, maka dapat disimpulkan bahwa secara statistic kedua kelompok data tersebut berdistribusi normal karena nilai signifikannya lebih besar dari 0,05 .

Hasil uji homogenitas tes akhir dari kedua kelas sampel dapat dilihat pada Tabel 4.

Tabel 4. Hasil Uji Homogenitas Varian

\begin{tabular}{l|l|llll}
\hline \multirow{2}{*}{ NILAI KOGNITIF } & \multirow{2}{*}{ Berdasarkan Rata-rata } & Statistik Levene & $d f 1$ & $d f 2$ & Sig. \\
\cline { 3 - 6 } & & 0,009 & 1 & 67 & 0,924 \\
\hline
\end{tabular}

Berdasarkan hasil analisis menunjukkan nilai sig. sebesar 0,924. Oleh karena nilai signifikan $>0,05$ sehingga dapat disimpulkan bahwa variasi kelas kontrol dan eksperimen homogen yaitu tidak terdapat perbedaan varian antara kelompok eksperimen dan kelompok kontrol.

Hasil uji hipotesis ranah kognitif dari kedua kelas sampel dapat dilihat pada Tabel 5.

Tabel 5. Hasil Uji Hipotesis Penelitian

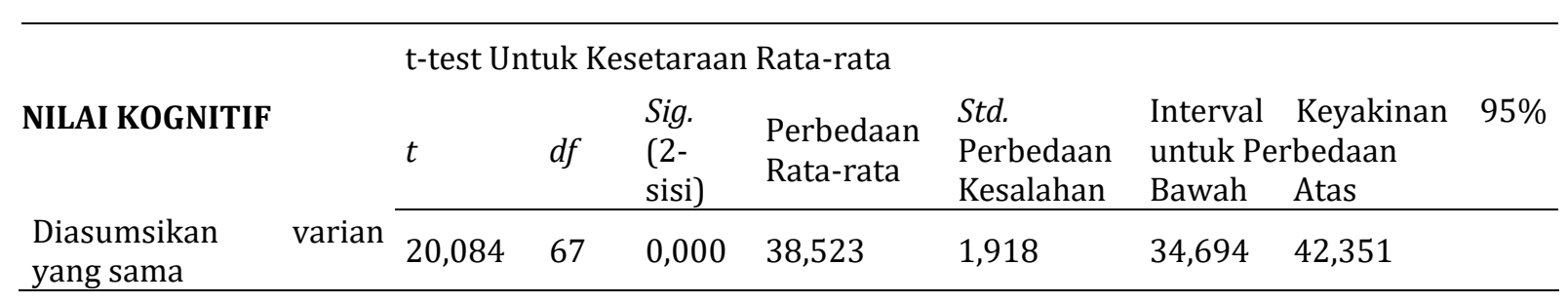


Nilai $\mathrm{t}$ hitung menunjukan nilai 20,084 dan $\mathrm{t}$ tabel dengan 0,025 dan $\mathrm{df}=67$ adalah 2,2928, $\mid \mathrm{t}$ hitung $|>| \mathrm{t}$ tabel $\mid(20,084>2,2928)$ maka $\mathrm{H}_{0}$ ditolak dan $\mathrm{H}_{1}$ diterima.

1) Prestasi Belajar

Berdasarkan analisis prestasi belajar siswa diketahui rata-rata prestasi belajar kelompok ekperimen lebih tinggi dibandingkan dengan kelompok kontrol. Dari pengujian hipotesis menunjukan bahwa prestasi belajar siswa dengan metode mind mapping menggunakan aplikasi mi-Mind serta Edmodo lebih tinggi dibandingkan siswa yang belajar dengan metode ceramah menggunakan media powerpoint. Dengan kata lain terdapat pengaruh dan perbedaan peningkatan prestasi belajar yang lebih baik jika pembelajaran dengan metode mind mapping menggunakan aplikasi mi-Mind serta Edmodo. Dengan demikian dengan adanya metode mind mapping menggunakan aplikasi mi-Mind serta Edmodo mampu membuat pembelajaran lebih efektif, efisien dan menghemat waktu. Karena metode mind mapping dapat membantu memperjelas penyajian pesan dan informasi sehingga memperlancar dan meningkatkan proses dan prestasi belajar serta dapat memberikan kesamaan pengalaman kepada siswa. Pembelajaran juga tidak hanya dalam tatap muka saja namun pembelajaran dengan menggunakan aplikasi mi-Mind serta Edmodo bisa dilakukan dimana saja dan kapan saja. Hal ini membuat pembelajaran Komputer dan Jaringan Dasar semakin bagus. Siswa yang tidak hadir saat tatap muka juga bisa belajar aplikasi mi-Mind serta Edmodo.

2) Respon Siswa

Dari hasil perhitungan angket respon siswa terhadap pembelajaran dengan metode mind mapping menggunakan aplikasi mi-Mind serta Edmodo persentase tertinggi diperoleh pada kategori sangat positif sebanyak 1 , kategori positif sebanyak 33 , cukup positif sebanyak 0 , kurang positif sebanyak 0 , dan sangat kurang positif sebanyak 0. Sehingga dapat disimpulkan bahwa respon siswa setelah menggunakan pembelajaran dengan metode mind mapping menggunakan aplikasi mi-Mind serta Edmodo adalah positif.

Menurut peneliti hal ini sangat baik untuk diterapkan di sekolah dan pada mata pelajaran yang lainnya karena pembelajaran yang lebih efektif, efisien dan inofativ serta menghemat waktu dan bisa belajar dimana saja membuat siswa tetap bisa belajar walau tidak dengan bertatap muka di kelas

\section{Simpulan dan saran}

Berdasarkan hasil penelitian dan pembahasan yang disajikan, dapat diajukan beberapa kesimpulan sebagai berikut. (1) Terdapat perbedaan peningkatan prestasi belajar antara siswa dengan metode mind mapping menggunakan aplikasi mi-Mind serta Edmodo dan siswa dengan metode ceramah menggunakan media powerpoint. Artinya pembelajaran dengan metode mind mapping menggunakan aplikasi mi-Mind serta Edmodo $\neg$ memberikan pengaruh yang signifikan (positif) terhadap prestasi belajar siswa. (2) Terdapat hasil bahwa respon siswa terhadap pembelajaran Komputer dan Jaringan Dasar siswa dengan dengan metode mind mapping menggunakan aplikasi mi-Mind serta Edmodo persentase tertinggi diperoleh pada kategori positif yaitu sebanyak 33. Sehingga pembelajaran dengan dengan metode mind mapping menggunakan aplikasi mi-Mind serta Edmodo berpengaruh positif terhadap Prestasi Belajar siswa.

\section{Daftar Rujukan}

Ainiyah, Z. (2015). Penggunaan Edmodo Sebagai Media Pembelajaran E-Learning Pada Mata Pelajaran Otomatisasi Perkantoran di SMKN 1 Surabaya.

Arikunto, S. (2009). Dasar-Dasar Evaluasi Pendidikan . Jakarta: Bumi Aksara.

Arsyad, A. (2011). Media Pembelajaran. Jakarta: PT RajaGrafindo Persada.

Basori. (2013). Pemanfaatan Social Learning Network "Edmodo" Dalam Membantu Perkuliahan Teori Bodi Otomotif Di Prodi PTM JPTK FKIP UNS.

Buka, W. S. (2013). Penerapan Model Mind Map Pada Mata Pelajaran Pengetahuan Dasar Teknik Mesin (PDTM) Untuk Meningkatkan Kreativitas Siswa Kelas X Di SMK N 1 Seyegan.

Buzan, T. (2005). The Ultimate Book Of Mind Maps. Harper Collins Publisher. 
Candiasa, I. M. (2010). Statistik Univariat dan Bivariat Disertai Aplikasi SPSS. Singaraja: Unit Penerbitan Undiksha.

Dahar, R. W. (2011). Teori-Teori Belajar dan Pembelajaran. Bandung.

Divayana, D. G. (2017). Asesmen dan Evaluasi. Singaraja: Undiksha Press.

Frey, C. (2010). Power Tips \& Strategies For Mind Maping Software Third Edition . USA.

Hamalik, O. (2001). Proses Belajar Mengajar. Jakarta: PT Bumi Aksara.

Hamalik, O. (2002). Perencanaan Pengajaran Berdasarkan Pendekatan Sistem. Jakarta: PT Bumi Aksara.

Harahap, R. (2013). Efek Model Pembelajaran Advance Organizer Berbasis Peta Konsep dan Aktivitas Terhadap Prestasi Belajar Fisika Siswa. Eksperimen

Kuswanto, D. (2012). Statistik Untuk Pemula dan Orang Awam. Jakarta: Laskar Aksara

Munir. (2009). Pembelajaran Jarak Jauh Berbasis Teknologi Informasi dan Komunikasi. CV. Alfabeta.

Prawiradilaga, D. S. (2013). Mozaik Teknologi Pendidikan : E-Learning. Jakarta: Prenadamedia Group

Silaban, R. (2012). Pengaruh Media Mind Maping Terhadap Kreativitas dan Prestasi Belajar Kimia Siswa SMA Pada Pembelajaran Menggunakan Advance Organizer. Eksperimen.

Sugihartini, N. (2016). Strategi Pembelajaran Pendekatan Pembelajaran Inovatif Disertai Dengan Aplikasi Pembelajaran Bidang Teknologi Informasi dan Komunikasi (TIK). Undiksha Press.

Sugiyono, P. D. (2008). Metode Penelitian Pendidikan (Pendekatan Kuantitatif, Kualitatif, dan R\&D). Bandung: CV Alfabeta.

Swari, N. P. (2018). Meningkatkan Prestasi Belajar Siswa Melalui Penggunaan E-Learning Edmodo di SMK Negeri 3 Singaraja.

Wirda. (2014). Pengaruh Penggunaan Media Pembelajaran Elektronik Berbasis Edmodo Terhadap Prestasi Belajar Siswa Pada Mata Diklat Melakukan Instalasi Sound System Kelas XI Teknik Audio Video Di SMK N 1 Kinali.

Zainal, R. V. (2014). Mengelola Pendidikan Secara Profesional untuk Meraih Mutu dengan Pendekatan Bisnis. Jakarta: PT Gramedia Pustaka Utama. 